\title{
Nutrients intake and digestibility in sheep fed with residue from the extraction of tamarind pulp
}

\section{Consumo e digestibilidade de nutrientes em ovinos alimentados com resíduo da extração da polpa de tamarindo}

\author{
Luiz Juliano Valério Geron ${ }^{1 *}$; Fabiana Gomes da Costa ${ }^{2}$; Jocilaine Garcia ${ }^{1}$; \\ Anderson de Moura Zanine ${ }^{3}$; Edimar Barbosa de Oliveira²; Luciano da Silva Cabral³; \\ Maria Aparecida Pereira Pierangeli ${ }^{1}$; Silvia Cristina de Aguiar ${ }^{1}$
}

\begin{abstract}
This study aimed to evaluate nutrient intake and digestibility by sheep fed diets containing residue from the extraction of tamarind pulp (RETP). We used four sheep with a mean body weight (BW) of 40.38 $\mathrm{kg}$, whose pens were distributed in a Latin square design. The diet treatments contained 0, 5, 10 and $15 \%$ of RETP. The variables were subjected to analysis of variance and the differences observed were tested using regression equations at 5\% significance. The intake of dry matter (DM), organic matter $(\mathrm{OM})$, crude protein (CP), total carbohydrates (TC), and non-fiber carbohydrates (NFC), expressed in $\mathrm{g}$ day $^{-1}, \% \mathrm{BW}$ and $\mathrm{g} \mathrm{kg}^{0,75-1}$, were not significantly affected $(\mathrm{p}>0.05)$ by the inclusion of RETP. The intake of ether extract (EE) and neutral detergent fiber (NDF) showed a linear increase $(p<0.05)$ as RETP content rose. However, the digestibility of DM, CP, TC, and total digestible nutrients (TDN) decreased linearly $(\mathrm{p}<0.05)$, while the digestibility of EE, NDF, ADF, and NFC, with average values of $62.12 \% ; 79.95 \% ; 41.59 \% ; 37.12 \%$, and $91.57 \%$, respectively, were not significantly affected $(\mathrm{p}>0.05)$ when RETP was included in the diet. The inclusion of up to $15 \%$ of the residue from the extraction of tamarind pulp changes the intake of ether extract and neutral detergent fiber, and reduced dry matter, crude protein, and total carbohydrates in the sheep's diet.
\end{abstract}

Key words: Confinement, crude protein, fruit, neutral detergent fiber

\section{Resumo}

Objetivou-se avaliar o consumo e a digestibilidade nutrientes em ovinos alimentados com rações contendo resíduo da extração da polpa de tamarindo (REPT). Foram utilizados quatro ovinos com peso corporal (PC) médio de 40,38 kg, distribuídos em um delineamento em quadrado latino. As rações apresentaram inclusão de $0 \%, 5 \%, 10 \%$ e $15 \%$ de REPT. As variáveis estudadas foram submetidas à análise de variância e as diferenças observadas foram testadas utilização equação de regressão a $5 \%$ de significância. O consumo de matéria seca (MS), matéria orgânica (MO), proteína bruta (PB), carboidratos totais (CHT) e carboidratos não fibrosos (CNF) expressos em $\mathrm{g} \mathrm{dia}^{-1}, \% \mathrm{PC}$ e g kg ${ }^{0,75-1}$ não apresentaram efeito $(\mathrm{p}>0,05)$ conforme a inclusão do REPT. O consumo de extrato etéreo (EE) e fibra em detergente neutro (FDN) apresentaram aumento linear $(\mathrm{p}<0,05)$ quando expressos em $\mathrm{g} \mathrm{dia}^{-1}, \% \mathrm{PC}$

\footnotetext{
Profs., Universidade do Estado de Mato Grosso, UNEMAT, Pontes e Lacerda, MT, Brasil. E-mail: 1jgeron@yahoo.com.br; jo@ unemat.br

2 Discentes do Curso de Mestrado do Programa de Pós-Graduação em Ciências Animal, UFMT, Cuiabá, MT, Brasil. E-mail: fabiana_gcosta@hotmail.com; mariaisabelmt@hotmail.com

${ }^{3}$ Profs., Universidade Federal de Mato Grosso, UFMT, Rondonópolis, MT, Brasil. E-mail: anderson.zanine@ibest.com.br; lucianoufmt@gmail.com

* Author for correspondence
} 
e $\mathrm{g} \mathrm{kg}^{0,75-1}$ com a inclusão do REPT. A digestibilidade da MS, PB, CHT e nutrientes digestíveis totais (NDT) reduziram linearmente ( $<<0,05$ ), enquanto, a digestibilidade do MO, EE, FDN, FDA e CNF não apresentaram efeito significativo ( $p>0,05$ ) conforme aumentou a inclusão do REPT, com valores médios de $62,12 \% ; 79,95 \% ; 41,59 \% ; 37,12 \%$ e $91,57 \%$, respectivamente. A inclusão de até $15 \%$ do resíduo da extração da polpa de tamarindo altera o consumo de extrato etéreo e fibra em detergente neutro e reduz a digestibilidade da matéria seca, proteína bruta e carboidratos totais nas rações de ovinos.

Palavras-chave: Confinamento, fibra em detergente neutro, fruta, proteína bruta

\section{Introduction}

Sheep production is a global industry because sheep are able to adapt to a wide variety of climates, reliefs, and vegetation. The largest herds are found in the continents of Asia, Africa, and Oceania (VIANA, 2008).

Data published by the IBGE (2010) showed that there had been a $3.4 \%$ increase in the number of Brazilian herd sheep. The largest rise was in the Midwest region with $12.4 \%$, and of this, about $24.1 \%$ of the increase occurred in the State of Mato Grosso. This large increase in sheep production in the Midwest region has led to improvements in market presence, ease of feeding, the availability of suitable areas, reproductive function, sanitary control facilities, and production $\left(\mathrm{ha}^{-1}\right.$ year $\left.^{-1}\right)$ of products other than those derived from sheep skins (UNB, 2001).

Over the last decade, meat production has become the main objective of sheep production. The price paid to producers rose, making it an attractive and profitable activity (GERON et al., 2012). The stimulus for the increased production of sheep occurred because an increasing number of animals were slaughtered in Brazil. Even with this increase in production, Brazil still imports mutton for the consumer market because the meat supply is still not enough to supply the market (OSÓRIO et al., 1996; VIANA, 2008).

The type of feed used is of great importance in streamlining and improving the profitability of sheep production systems. Food intake should adequately meet maintenance, development, production, and pregnancy needs. Thus, when sheep are given a quality feed, they grow faster, reproduce early, and become more productive (SOUZA JÚNIOR, 2004; RODRIGUES et al., 2013).

Brazil is a major producer of fruits and is fully integrated into the world markets. Part of this fruit production is processed, which generates large amounts of residue. For example, the orange juice industry is responsible for producing more than 1,150,000 tons citrus pulp per year. There has been research into whether agro-industrial residues can be used by ruminants, which would reduce environmental pollution associated with residue disposal and reduce the cost of animal feed (BARROSO et al., 2006, GERON et al., 2014).

The by-products of fruit are basically considered high calorie foods, with energy content values between 78 and $86 \%$ of total digestible nutrients. They also contain some vitamins, such as vitamin A, C, and B (VASCONCELOS et al., 2002; GURJÃO, 2006). Some of these residues (cashew, pineapple, tamarind, etc.) may have nutritional constraints because they contain anti-nutritional substances, such as tannin and phenolic compounds (GURJÃO, 2006; GERON et al., 2007). For this reason, previous research has established the amount and the best way to provide this residue to livestock (GOMES et al., 2007) without harming animal performance, which should improve the economic viability of livestock production.

The tropical fruit, tamarind (Tamarindus indica L.), has excellent organoleptic qualities, such as a pleasant aroma and a sweet-sour taste. Tamarind fruits are widely used in the manufacture of soft drinks, ice creams, pastes, jams, and liqueurs. It is also used as an ingredient in sauces and condiments, 
and is primarily grown on family farms in the Midwest and Northeast of Brazil (PEREIRA et al., 1986).

Ishola and Agbaji (1990) characterized tamarind pulp and showed that it contains calcium mineral salts, magnesium and phosphorus, carbohydrates, and organic acids such as ascorbic, malic, tartaric, and citric acids. Similarly, Lefevre (1971) reported significant quantities of potassium (78 $\mathrm{mg} 100$ $\mathrm{g}^{-1}$ ), phosphorus (119 mg $100 \mathrm{~g}^{-1}$ ), calcium (74 mg $100 \mathrm{~g}^{-1}$ ), and vitamin A (20 to $50 \mathrm{IU}$ ) in tamarind pulp. The use of fruits to make pulp extracts for use in the food industry is a growing business in Brazil (GURJÃO, 2006). However, it has passive environmental drawbacks because residues, such as bark, seeds, and pulp remnants accumulate in the courtyards of agribusinesses, and these wastes should have an appropriate destination or else they may contaminate the environment and groundwater.

Thus, the objective of this study was to evaluate the inclusion of $0 \%, 5 \%, 10 \%$, or $15 \%$ residue from the extraction tamarind pulp (RETP) in sheep feed, and assess its effects on nutrient intake and the digestibility of rations containing $50 \%$ feed concentrates.

\section{Material and Methods}

The study was conducted at the Setor de Metabolismo Animal (SeMA) and the Laboratório de Análise de Alimentos e Nutrição Animal (LAANA), University Campus of Pontes and Lacerda, Universidade do Estado de Mato Grosso (UNEMAT). The site is located at $15^{\circ} 19^{\prime} 05^{\prime \prime}$ south latitude and $59^{\circ} 13$ '26" west longitude, at an altitude of 295 meters above sea level.

The climate of the Upper Valley region of Guapore-MT is classified as tropical continental, or as a wet and dry type of Aw second Koppen (SEPLAN, 2007).

We used four mongrel sheep, with a mean body weight (BW) of $40.38 \pm 2.07 \mathrm{~kg}$. Each sheep was housed in a metabolism cage, which contained a feeder and equipment for providing water. Fifteen days before the beginning of the experimental period, the animals were wormed with an Ivermectin based product.

A Latin square experimental design $(4 \times 4)$ was used with four animals, four periods, and four experimental diets that contained $0,5,10$, or $15 \%$ residue from the extraction tamarind pulp (RETP). The aim was to assess the effects of the four diets on nutrient intake and digestibility.

The residue from the extraction tamarind pulp was obtained from an existing agribusiness in the city of Pontes and Lacerda - MT. The residue consisted of fruit peel, seed, and pulp that had adhered to tamarind seed after extracting the fruit pulp.

The concentrated foods used in the preparation of the experimental rations were corn ground grain, cassava flour, soybean meal, residue from the extraction tamarind pulp, and urea. The volumeadding component was corn silage. The chemical composition of the feed is shown in Table 1.

The experimental rations contained $0 \%, 5 \%$, $10 \%$ and $15 \%$ of residue from the extraction tamarind pulp. The proportion of the components used in the experimental rations was $50 \%$ corn silage and $50 \%$ concentrate. The rations were balanced to give an average of $15 \%$ crude protein (isoproteic) and 69\% total digestible nutrients (isocaloric) as recommended by the NRC (2007) to meet maintenance requirements and produce a weight gain of $150 \mathrm{~g} \mathrm{animal}^{-1}$ day $^{-1}$ (Table 2).

The sheep had access to water through individual troughs. They were supplied $10 \mathrm{~g}$ of mineral mixture per day per animal ( $5 \mathrm{~g}$ of salt meal ${ }^{-1}$ animal- ${ }^{1}$ ), which was added to the experimental concentrates twice a day when the sheep were fed their rations. The chemical composition of the mineral salt used in this study was $120 \mathrm{~g}$ of $\mathrm{Ca} \mathrm{kg}^{-1}, 85 \mathrm{~g}$ of $\mathrm{P} \mathrm{kg}^{-1}, 16 \mathrm{~g}$ of $\mathrm{S} \mathrm{kg}^{-1}, 148 \mathrm{~g}$ of $\mathrm{Na} \mathrm{kg}^{-1}, 50 \mathrm{mg}$ of Co kg-1, $500 \mathrm{mg}$ of $\mathrm{Cu} \mathrm{kg}^{-1}, 16 \mathrm{mg}$ of $\mathrm{Se} \mathrm{kg}^{-1}$, and 4,800 mg of $\mathrm{Zn} \mathrm{kg}^{-1}$. 
Table 1. Chemical composition of experimental foods.

\begin{tabular}{lrrrrrc}
\hline Variables & \multicolumn{7}{c}{ Experimental food } \\
\cline { 2 - 6 } & COS $^{1}$ & \multicolumn{1}{c}{ CGG $^{2}$} & CAF $^{3}$ & SOM $^{4}$ & RETP $^{5}$ & Ureia $^{6}$ \\
\hline Dry matter \% & 25.12 & 91.68 & 90.74 & 90.35 & 83.49 & 97.68 \\
Organic matter \% & 92.16 & 97.22 & 94.97 & 93.37 & 96.28 & -6 \\
Crude protein \% & 8.25 & 9.83 & 2.95 & 47.55 & 8.52 & 282.6 \\
Ether extract \% & 1.61 & 4.34 & 0.30 & 1.51 & 1.09 & - \\
Neutral detergent fiber \% & 68.58 & 13.63 & 10.30 & 17.80 & 50.62 & - \\
Acid detergent fiber \% & 41.03 & 11.31 & 4.13 & 16.66 & 38.02 & - \\
Crude fiber \% & 32.30 & 9.05 & 3.30 & 13.33 & 30.42 & - \\
No-nitrogen extract \% & 52.52 & 74.00 & 88.42 & 31.23 & 57.47 & - \\
Total carbohydrates \% & 82.30 & 83.05 & 91.72 & 44.31 & 86.67 & - \\
No-fibrous carbohydrate \% & 13.72 & 69.42 & 81.42 & 26.51 & 36.04 & - \\
Mineral matter \% & 4.79 & 2.78 & 5.03 & 6.38 & 2.50 & - \\
Total digestible nutrients \% & 62.30 & 86.03 & 74.00 & 80.73 & 54.40 & - \\
\hline
\end{tabular}

${ }^{1} \mathrm{COS}$ : corn silage, ${ }^{2} \mathrm{CGG}$ : corn ground grain, ${ }^{3} \mathrm{CAF}$ : cassava flour, ${ }^{4} \mathrm{SOM}$ : soybean meal, ${ }^{5} \mathrm{RETP}$ : residue from the extraction of tamarind pulp, ${ }^{6}$ trace nutrient in the experimental food. Total carbohydrates (TC) $=$ OM - [EE + CP] second Sniffen et al. (1992) and not fibrous carbohydrate $(\mathrm{NFC})=100-(\mathrm{CP}+\mathrm{NDF}+\mathrm{EE}+\mathrm{MM})$ according Weiss (1999).

Table 2. Percentage and chemical composition of experimental diets containing different levels of inclusion of the residue from the extraction of tamarind pulp (RETP) provided to sheep.

\begin{tabular}{lcccc}
\hline \multirow{2}{*}{ Foods } & \multicolumn{3}{c}{ Inclusion levels of the residue from the extraction of tamarind } \\
& \multicolumn{3}{c}{ pulp (RETP) in experimental diets } \\
\cline { 2 - 5 } & $0 \%$ & $5 \%$ & $10 \%$ & $15 \%$ \\
\hline Corn silage & 50.00 & 50.00 & 50.00 & 50.00 \\
Corn ground grain & 15.40 & 16.00 & 23.00 & 23.00 \\
Cassava flour & 19.00 & 14.00 & 4.00 & 0.00 \\
Soybean meal & 15.00 & 14.40 & 12.40 & 11.40 \\
Residue from the extraction of tamarind pulp & 0.00 & 5.00 & 10.00 & 15.00 \\
Urea & 0.60 & 0.60 & 0.60 & 0.60 \\
Total & 100.00 & 100.00 & 100.00 & 100.00 \\
\hline Chemical composition & & & & \\
Dry matter & 58.06 & 57.70 & 57.41 & 57.06 \\
Organic matter & 93.10 & 93.19 & 93.45 & 93.53 \\
Crude protein & 15.03 & 15.08 & 14.95 & 14.80 \\
Ether extract & 1.76 & 1.81 & 2.11 & 2.14 \\
Neutral detergent fiber & 41.02 & 43.01 & 45.11 & 47.05 \\
Acid detergent fiber & 25.54 & 27.20 & 29.15 & 30.72 \\
Crude fiber & 20.43 & 21.76 & 23.32 & 24.58 \\
Non-nitrogenous extractives & 59.14 & 57.85 & 56.44 & 55.46 \\
Total carbohydrates & 78.01 & 79.99 & 78.08 & 78.30 \\
Non-fibrous carbohydrates & 37.00 & 34.98 & 32.97 & 31.25 \\
Mineral matter & 4.74 & 4.59 & 4.28 & 4.14 \\
Total digestible nutrients & 70.57 & 69.92 & 69.35 & 68.30 \\
\hline
\end{tabular}


The rations were supplied ad libitum so that there were approximately $10 \%$ of leftovers each day. Feeding was split into two meals a day, at 06:00 am and at 18:00 pm. The leftovers were examined before the first daily meal.

The nutrient digestibility testing lasted 84 days, and it was divided into four experimental periods lasting 21 days each. The animals were allowed to adapt for 15 days and then there were 6 days when the leftovers and feces were collected and sampled. The experimental collection period included the measurement of the total amount of feces and leftovers generated per animal day $^{-1}$ and analysis of food, leftover, and fecal samples. The adaptation and collection period management was carried out as described by Silva and Leão (1979).

Feces from each animal were collected in a napa bag during the trial period. Feces were weighed each morning and homogenized, which produced compound samples corresponding to $10 \%$ of the total collective original weight. The samples were packed in plastic bags, marked with the animal and experimental period, and stored at $-10^{\circ} \mathrm{C}$ for later analysis.

The food, leftover, and feces samples were dried at $55^{\circ} \mathrm{C}$ for 72 hours and processed in a Wiley mill using a $1 \mathrm{~mm}$ sieve. Then equal amounts (based on dry weight) from each sample were homogenized to form composite samples of the feces and leftovers animal $^{-1}$ period $^{-1}$ experimental ration ${ }^{-1}$.

The nitrogen content of the food, leftovers, and feces was obtained using the semi-micro-Kjeldahl method, with 6.25 as the conversion factor for crude protein (CP). Mineral matter (MM) analysis was performed by incineration in an oven at $600^{\circ} \mathrm{C}$; organic matter $(\mathrm{OM})$ was estimated by difference (100 - MM); and the ether extract (EE) content was determined by extraction after washing with petroleum ether (AOAC, 2007).
The determination of the neutral detergent fiber (NDF) and acid detergent fiber (ADF) contents of the food, leftovers, and feces was performed according to Van Soest et al. (1991) without the use of sulfite sodium and without correcting the NDF and ADF values for the ash content of the fiber. Total carbohydrate (TC) contents of the food, leftovers, and feces were calculated from the equation: $\mathrm{TC}=\mathrm{OM}-[\mathrm{CP}+\mathrm{EE}]($ SNIFFEN et al., 1992). The non-fiber carbohydrate (NFC) content of feed and feces was determined by the formula $\mathrm{NFC}=100-(\mathrm{CP}+\mathrm{NDF}+\mathrm{EE}+\mathrm{MM})$ the according Weiss (1999), without protein correcting of NDF.

The total digestible nutrient (TDN) contents of the experimental rations were obtained from the equation by Sniffen et al. (1992) where TDN = DCP + 2.25 DEE + TCD (DCP, digestible protein; DEE, digestible ether extract; and TCD, total digestible carbohydrates).

Nutrient digestibility was obtained from the equation: [((nutrient contained in the feed $g$ leftovers of nutrient $g$ ) - nutrient contained in feces g)/nutrient consumed g] $\times 100$ as demonstrated by Geron et al. (2013).

The variables were subjected to analysis of variance using SAEG software (UFV, 2007), with a significance value of $p \leq 0.05$. If the RETP level treatments in the experimental rations were significant, then regression analysis was performed to ascertain whether the significance effect was a linear or quadratic relationship at 5\% significance.

\section{Results and Discussion}

The $0 \%, 5 \%, 10 \%$, and $15 \%$ RETP levels in the animal feed did not change ( $p>0.05)$ the intake of $\mathrm{DM}, \mathrm{OM}, \mathrm{CP}, \mathrm{TC}$, and NFC (expressed in $\mathrm{g} \mathrm{kg}^{0.75-1}$, $\mathrm{g} \mathrm{day}^{-1}$, and $\%$ BW) (Table 3). 
Table 3. Daily average intake of dry matter (IDM), organic matter (IOM), crude protein (ICP), ether extract (IEE), neutral detergent fiber (INDF) and acid (IFDA), total carbohydrates (ICT), and non-fiber carbohydrates (INFC) by sheep fed with rations containing residue from the extraction of tamarind pulp.

\begin{tabular}{|c|c|c|c|c|c|c|}
\hline \multirow[t]{2}{*}{ Variables } & \multicolumn{4}{|c|}{$\begin{array}{l}\text { Inclusion levels of the residue from the extraction of tamarind } \\
\text { pulp (RETP) in experimental diets }\end{array}$} & \multirow[t]{2}{*}{ Regres. } & \multirow{2}{*}{$\begin{array}{l}\mathrm{CV} \\
(\%)\end{array}$} \\
\hline & $0 \%$ & $5 \%$ & $10 \%$ & $15 \%$ & & \\
\hline IDM $\mathrm{g} \mathrm{kg}^{0,75-1}$ & 80.84 & 84.27 & 86.63 & 92.02 & 85.94 & 10.46 \\
\hline IDM \% BW & 3.24 & 3.33 & 3.42 & 3.68 & 3.42 & 11.26 \\
\hline IDM g day $^{-1}$ & $1,268.16$ & $1,366.22$ & $1,409.67$ & $1,441.69$ & $1,371.44$ & 8.51 \\
\hline IOM $\mathrm{g} \mathrm{kg}^{0,75-1}$ & 75.02 & 78.34 & 80.76 & 85.76 & 79.97 & 10.51 \\
\hline IOM \% BW & 3.00 & 3.09 & 3.19 & 3.44 & 3.18 & 11.30 \\
\hline $\mathrm{IOM}_{\mathrm{g}}$ day $^{-1}$ & $1,177.00$ & $1,270.03$ & $1,314.24$ & $1,346.10$ & $1,276.84$ & 8.56 \\
\hline ICP $\operatorname{g~kg}^{0,75-1}$ & 20.78 & 21.44 & 21.67 & 22.21 & 21.53 & 7.99 \\
\hline ICP \% BW & 0.83 & 0.85 & 0.86 & 0.89 & 0.86 & 8.58 \\
\hline ICP g day ${ }^{-1}$ & 326.03 & 347.77 & 352.24 & 348.04 & 343.52 & 6.93 \\
\hline IEE $\operatorname{g~kg}^{0,75-1}$ & 0.49 & 1.35 & 1.87 & 1.98 & 1 & 19.26 \\
\hline IEE \% BW & 0.02 & 0.05 & 0.07 & 0.08 & 2 & 19.13 \\
\hline${\text { IEE } g \text { day }^{-1}}^{1}$ & 7.46 & 22.15 & 30.41 & 31.08 & 3 & 20.42 \\
\hline INDF $\mathrm{g} \mathrm{kg}^{0,75-1}$ & 29.48 & 33.03 & 34.43 & 42.06 & 4 & 12.04 \\
\hline INDF \% BW & 1.18 & 1.31 & 1.36 & 1.68 & 5 & 13,02 \\
\hline $\mathrm{INDF}_{\mathrm{g}}$ day $^{-1}$ & 463.33 & 534.61 & 560.17 & 658.83 & 6 & 9.36 \\
\hline IADF $\mathrm{g} \mathrm{kg}^{0,75-1}$ & 19.32 & 22.03 & 22.75 & 24.51 & 22.15 & 11.23 \\
\hline IADF $\%$ PCV & 0.77 & 0.87 & 0.90 & 0.98 & 0.88 & 11.99 \\
\hline IADF $g \mathrm{dia}^{-1}$ & 303.59 & 357.04 & 370.70 & 384.01 & 7 & 9.35 \\
\hline ITC $\mathrm{g} \mathrm{kg}^{0,75-1}$ & 63.69 & 65.37 & 67.35 & 71.93 & 67.09 & 8.27 \\
\hline ITC \% BW & 2.56 & 2.59 & 2.64 & 2.85 & 2.66 & 11.01 \\
\hline ITC $g$ day $^{-1}$ & 999.64 & $1,059.41$ & $1,096.12$ & $1,127.08$ & $1,070.56$ & 10.28 \\
\hline INFC $\mathrm{g} \mathrm{kg}^{0,75-1}$ & 34.21 & 32.34 & 31.23 & 29.88 & 31.92 & 6.18 \\
\hline INFC \% BW & 1.37 & 1.28 & 1.23 & 1.19 & 1.27 & 8.28 \\
\hline INFC $g$ day $^{-1}$ & 536.31 & 524.80 & 507.41 & 468.26 & 509.20 & 7.57 \\
\hline \multicolumn{7}{|c|}{$\begin{array}{l}{ }^{1} \hat{\mathrm{Y}}=0.675044+0.100016 \mathrm{X}\left(\mathrm{R}^{2}=0.69\right),{ }^{2} \hat{\mathrm{Y}}=0.267524+0.00398301 \mathrm{X}\left(\mathrm{R}^{2}=0.69\right),{ }^{3} \hat{\mathrm{Y}}=10.9062+1.58238 \mathrm{X}(\mathrm{R} \\
=0.66),{ }^{4} \hat{\mathrm{Y}}=28.8826+0.782312 \mathrm{X}\left(\mathrm{R}^{2}=0.62\right),{ }^{5} \hat{\mathrm{Y}}=1.14813+0.0311589 \mathrm{X}\left(\mathrm{R}^{2}=0.56\right),{ }^{6} \hat{\mathrm{Y}}=462.424+12.2411 \mathrm{X} \\
\left(\mathrm{R}^{2}=0.67\right),{ }^{7} \hat{\mathrm{Y}}=315.595+5.09891 \mathrm{X}\left(\mathrm{R}^{2}=0.47\right) .\end{array}$} \\
\hline
\end{tabular}

$\mathrm{g} \mathrm{kg}^{0,75-1}$ : grams per kilogram of metabolic weight; \%BW: body weight; $\mathrm{g} \mathrm{day}^{-1}$ : grams per day; Regres.: regression equation; and $\% \mathrm{CV}$ : coefficient of variation.

The average value observed for DM intake by the sheep was $1,371.45 \mathrm{~g} \mathrm{day}^{-1}$. There was a $12.04 \%$ difference between the DM at $15 \% \operatorname{RETP}(1,441.45$ $\left.\mathrm{g} \mathrm{day}^{-1}\right)$ and at $0 \% \operatorname{RETP}\left(1,268.16 \mathrm{~g} \mathrm{day}^{-1}\right)$. This observation indicates that the inclusion of RETP does not affect the acceptability of the rations to sheep fed with $15 \%$ residue in the feed. The RETP diets had higher CP, EE, and NDF (Table 1) contents than cassava flour because the inclusion of the residue led to the reduction of cassava flour in the feed (Table 2). This fact may have contributed to the positive associative effect between DM intake and the ingredients in the experimental diets after the inclusion of RETP.

Rodrigues et al. (2013) evaluated the use of $0 \%$, $7 \%, 14 \%, 21 \%$, and $28 \%$ of sunflower cake residue from the biodiesel industry in diets containing $40 \%$ forage and $60 \%$ concentrate, which resulted 
in a CP of $13.80 \%$ and a TDN of $66.00 \%$. They demonstrated that there was no change $(p>0.05)$ in DM intake by sheep when subjected to the diets. Their mean value of $3.42 \% \mathrm{PC}$ was the same as that observed in this study (3.42\% PC).

According to Cunha et al. (2009), when pineapple residue was added to feed, the DM intake value was 3.8\% BW for sheep receiving a diet containing $35 \%$ pineapple residue, $45 \%$ of grass hay, and $20 \%$ maniçoba hay. The sheep grew satisfactorily and the weight gain averaged $170 \mathrm{~g}_{\text {animal }}{ }^{-1}$ day $^{-1}$.

According Barroso et al. (2006), grape residue $(50 \%)$, combined with a number of different energy sources (50\%), led to an average DM intake by sheep of $1,166.33 \mathrm{~g}$ animal $^{-1}$ day $^{-1}$, which was similar to the average DM intake value of 1,371.45 $\mathrm{g}_{\text {animal }}{ }^{-1}$ day $^{-1}$ observed in this study.

A study conducted by Geron et al. (2013), with lambs fed with $20 \%, 40 \%, 60 \%$, and $80 \%$ concentrates in their diets, showed that on average, diets with $40 \%$ concentrate improved DM intake, so the diets used in this study, which had a ratio of $50 \%$ concentrate and 50\% roughage, was close to the maximum suggested DM intake. This indicated that including 15\% RETP in the sheep's diet would not interfere with DM intake and consequently the acceptability of the ration.

The inclusion of RETP in sheep rations had a linear relationship $(p<0.05)$, and the EE and NDF intakes are shown in Table 3. The maximum intake observed for EE and NDF was 31.08 and 658.83 $\mathrm{g}_{\text {animal }}{ }^{-1}$ day $^{-1}$ at $15 \%$ of RETP, respectively. The increased content of EE and NDF (Table 2) in the diets containing higher levels of RETP was probably a result of the greater amount of ground corn grain added to these diets to balance the protein and energy content. The $12.04 \%$ variation observed in the DM intake between the $0 \%$ and 15\% RETP diets may also have contributed to this linear increase in the intake of EE and NDF (Table 3).

The RETP levels had no significant effects $(p>0.05)$ on NFC intake (Table 3). However, the
NFC intake at $15 \%$ RETP was $468.26 \mathrm{~g}^{-1}$ day ${ }^{-1}$, i.e., $12.69 \%$ lower than the 0\% RETP feed (536.31 $\left.\mathrm{g} \mathrm{day}^{-1}\right)$. This fact may be partly explained by the higher $(\mathrm{p}<0.05)$ NDF intake observed for the diets with larger RETP contents. Moreover, higher RETP levels in the rations led to a lower CNF content in the diets (Table 2), which may have contributed to the variation in NFC intake in this study.

The size of the observed values for NDF, AD F, NFC, and CT in the rations may be influenced by associative effects between the various ingredients in the rations, such as the ratio of the proportions of roughage and concentrates in the diets (GERON et al., 2013), and the amount of cassava flour in the rations, which increases feed dustiness and hence the acceptability of the feed (ZEOULA et al., 2003).

The inclusion of RETP in sheep diets linearly decreased $(\mathrm{p}<0.05)$ digestibility of DM, CP, TC, and TDN (Table 4).

The diet with 15\% RETP showed 54.70\% DM digestibility, which was $13.49 \%$ lower than the $0 \%$ diet with $63.23 \% \mathrm{DM}$ digestibility. This observation agrees with that of Gurjão (2006), who reported that tamarind has therapeutic qualities, such as changing digestive transit and intestinal flora, and a laxative effect, all of which alter the digestion of nutrients.

Sheep fed with 15\% RETP had a DM intake that was $12.04 \%$ higher than the $0 \%$ RETP diet (Table 3 ). This may be because of changes in the rumen environment caused by the inclusion of RETP, which may have contributed to the lower DM digestibility $(p<0.05)$ and consequently may have influenced the search for more feed in the trough by the sheep. Another fact that can corroborate the idea that the RETP contains substances that facilitate change in the rumen is the value of TDN $(p<0.05)$, which also showed a decreasing linear effect $(\mathrm{p}<0.05)$ with the increased addition of RETP in the feed. There was a $9.79 \%$ rise in OM digestibility observed between the diets with $0 \%$ and $15 \%$ RETP (Table 4). The literature indicates that the 
substances modifying the rumen with ionophores (GALLOWAY et al., 1993) and propolis (ZEOULA et al., 2014) can alter the fermentation of organic matter, and thus reduce the energy associated with fermentation and the recovery of nutrients retained by the animals.

Table 4. Coefficients of variation (CV) and total digestibility coefficients (DC) for dry matter (DM), organic matter $(\mathrm{OM})$, crude protein $(\mathrm{CP})$, ether extract (EE), neutral detergent fiber (NDF) and acid fiber (ADF), total carbohydrates (TC), non-fibrous carbohydrate (NFC) and total digestible nutrients (TDN) for sheep fed with diets containing different amounts of residue from the extraction of tamarind pulp.

\begin{tabular}{lcccccc}
\hline \multirow{2}{*}{ Variables } & \multicolumn{3}{c}{$\begin{array}{l}\text { Inclusion levels of the residue from the extraction of tamarind pulp } \\
\end{array}$} & \multicolumn{9}{c}{ (RETP) in experimental diets } & \multirow{2}{*}{ Regres. } & \multirow{2}{*}{ CV \% } \\
\cline { 2 - 5 } & $0 \%$ & $5 \%$ & $10 \%$ & $15 \%$ & & \\
\hline DC DM & 63.23 & 63.36 & 61.82 & 54.70 & 1 & 5.76 \\
\hline DC OM & 64.24 & 63.42 & 62.86 & 57.95 & 62.12 & 5.50 \\
DC CP & 75.94 & 74.01 & 73.39 & 69.50 & 2 & 4.16 \\
DC EE & 81.62 & 79.61 & 79.45 & 79.11 & 79.95 & 9.45 \\
DC NDF & 46.91 & 40.62 & 39.90 & 38.94 & 41.59 & 16.80 \\
DC ANF & 41.30 & 39.42 & 34.71 & 33.05 & 37.12 & 22.56 \\
DC TC & 66.03 & 65.89 & 64.13 & 57.61 & 3 & 5.07 \\
DC NFC & 88.96 & 94.56 & 90.92 & 91.82 & 91.57 & 3.71 \\
NDT & 58.36 & 57.98 & 55.05 & 50.45 & 4 & 5.64 \\
\hline${ }^{1} \hat{\mathrm{Y}}=64.4496-0.522751 \mathrm{X}\left(\mathrm{R}^{2}=0.26\right),{ }^{2} \hat{\mathrm{Y}}=76.1966-0.398556 \mathrm{X}\left(\mathrm{R}^{2}=0.39\right),{ }^{3} \hat{\mathrm{Y}}=67.4678-0.540484 \mathrm{X}\left(\mathrm{R}^{2}=\right.$ \\
$0.30),{ }^{4} \hat{\mathrm{Y}}=59.4610-0.533358 \mathrm{X}\left(\mathrm{R}^{2}=0.56\right)$. & & \\
\hline
\end{tabular}

Regres.: regression equation and \% CV: coefficient of variation.

Cunha et al. (2009) found that sheep had a mean value of $63.8 \%$ for DM digestibility when fed with diets containing pineapple residue. Similarly, Leite et al. (2013) evaluated the nutritional value of cashew residue in feed for sheep and observed that DM digestibility had a mean value of $61.43 \%$. Thus, the values observed for DM digestibility in diets containing RETP is within the range observed in the literature for sheep fed residues from agriculture.

The 15\% RETP diet had a CP digestibility value of $57.95 \%$, which was $8.48 \%$ lower $(\mathrm{p}<0.05)$ than the $0 \%$ diet $(75.94 \%)$. However, there were no significant differences $(\mathrm{p}>0.05)$ for $\mathrm{CP}$ intake between the different RETP diets. This suggests that the RETP contains compounds such as tannins and phenolic compounds that interfere with the digestion of nutrients and energy by altering the rumen microflora, and consequently, the development of the rumen (GURJÃO, 2006). Thus, future studies need to assess the efficiency of microbial synthesis and in vitro digestibility to confirm the effect of tamarind and RETP on the dynamics of ruminal fermentation.

According to Leite et al. (2013), the CP digestibility of sheep fed diets containing cashew residue, wheat, and soybean meal had an average value of $42.53 \% \quad(p>0.05)$. The researchers suggested that the low value for CP digestibility may be related to the presence of tannin in pseudocashew fruit. Therefore, the presence of polyphenol compounds in RETP (GURJÃO, 2006) could also be causing the reduction in CP digestibility.

The variation in ADF digestibility from 41.30 to $33.05 \%$ for the diets containing RETP agrees with the data obtained by Cunha et al. (2009), who evaluated the use of pineapple residue in diets containing 
maniçoba and recorded a low ADF digestibility value of $49.86 \%$ for the diet containing $35 \%$ of pineapple residue, $45 \%$ hay, and $20 \%$ maniçoba. They suggested that this low ADF digestibility value was related to the presence of tannin in maniçoba, which probably explains what could be occurring in this study when RETP is included in the sheep diet because RETP also contains phenolic compounds (ISHOLA; AGBAJI, 1990).

According to Van Soest (1994), a high ADF content in the diet is associated with lower food digestibility. This explains how the ADF content of the diets (Table 2) is related to the variation observed for ADF digestibility among the treatments (Table 4), which was $19.98 \%$ lower for the $15 \%$ RETP (33.05\%) diet compared to the 0\% RETP $(41.30 \%)$ diet. In diets containing roughage and concentrate, the value for ADF digestibility usually tends to decrease when the DM intake and ADF levels increase due to shorter retention times in the rumen of the gastrointestinal tract (RAMOS et al., 2000; GERON et al., 2013).

The observed values for ADF digestibility in this study are close to the observed variation in the literature (CUNHA et al., 2009; GERON et al., 2013, LEITE et al., 2013), of $61.00 \%$ to $36.43 \%$, for sheep rations containing agribusiness residues.

The inclusion of up to $15 \%$ of residue from the extraction tamarind pulp in the sheep's diet reduces the intake of ether extract and neutral detergent fiber, and reduces the coefficients of total tract digestibility of dry matter, crude protein, total carbohydrates, and total digestible nutrients.

\section{Acknowledgements}

The authors thank the Fundação de Amparo à Pesquisa do Estado de Mato Grosso (FAPEMAT) for giving scientific initiation scholarships to students from the Animal Science Course to assist the development of this study.

\section{References}

ASSOCIATION OF OFFICIAL ANALYTICAL CHEMISTIS - AOAC. Official Methods of Analysis of Official Analytical Chemists International. $20^{\text {th }}$ ed. Arlington: AOAC, 2007. 3000 p.

BARROSO, D. D.; ARAUJO, G. G. L.; SILVA, D. S.; GONZAGA NETO, S.; MEDINA, F. T. Desempenho de ovinos terminados em confinamento com resíduo desidratado de vitivinícolas associado a diferentes fontes energéticas. Ciência Rural, Santa Maria, v. 36, n. 5, p. 1553-1557, 2006.

CUNHA, M. G. G.; OLIVEIRA, E. R.; RAMOS, J. L. F.; ALCÂNTARA, M. D. B. Conservação e utilização do resíduo de abacaxi na alimentação de ovinos no Curimatáu Ocidental da Paraíba. Tecnologia \& Ciências Agropecuária, João Pessoa, v. 3, n. 3, p. 55-62, 2009.

GALLOWAY, S. R. D. L.; GOETSCH, A. L.; PATIL, A.; FORSTER JÚNIOR, L. A.; JOHNSON, Z. B. Feed intake and digest by Holstein steer calves consuming lowquality grass supplemented with lasalocida or monensin. Canadian Journal of Animal Science, Ottawa, v. 73, n. 4, p. 869-879, 1993.

GERON, L. J. V.; MEXIA, A. A.; CRISTO, R. L.; GARCIA, J.; CABRAL, L. S.; TRAUTMANN, R. J. M.; MARTINS, O. S.; ZEOULA, L. M. Consumo, digestibilidade dos nutrientes e características ruminais de cordeiros alimentados com níveis crescentes de concentrado em ambiente tropical no Vale do Alto Guaporé. Semina: Ciências Agrárias, Londrina, v. 34, n. 5, p. 2497-2510, 2013.

GERON, L. J. V.; MEXIA, A. A.; GARCIA, J.; SILVA, M. M.; ZEOULA, L. M. Suplementação concentrada para cordeiros terminados a pasto sobre custo de produção no período da seca. Semina: Ciências Agrárias, Londrina, v. 33, n. 2, p. 797-808, 2012.

GERON, L. J. V.; MOURA, D. C.; RODRIGUES, D. N.; PAULA, E. J. H.; TRAUTAMM-MACHADO, R. J.; GARCIA, J.; SCHUMANN, A. M.; SILVA, D. A. Viabilidade econômica de tourinhos terminados em confinamento alimentados com diferentes teores de caroço de algodão em dietas elaboradas com co-produtos agroindustriais. Semina: Ciências agrárias, Londrina, v. 35, n. 3, p. 2673-2684, 2014. Suplemento 1.

GERON, L. J. V.; ZEOULA, L. M.; BRANCO, A. F.; ERKE, J. A.; PRADO, O. P. P.; JACOBI, G. Caracterização, fracionamento proteico, degradabilidade ruminal e digestibilidade in vitro da matéria seca e proteina bruta do resíduo de cervejaria úmido e fermentado. Acta Scientiaurum. Animal Science, Maringá, v. 29, n. 3, p. 291-299, 2007. 
GOMES, J. A. F.; LEITE, E. R.; RIBEIRO, T. P. Alimentos e alimentação de ovinos e caprinos no semiárido brasileiro. Sobral: EMBRAPA Caprinos, 2007. 38 p. (EMBRAPA Caprinos. Documentos, 67).

GURJÃO, K. C. O. Desenvolvimento, armazenamento e secagem de tamarindo (Tamarindus indica L.). 2006. Tese (Doutorado em Agronomia) - Universidade Federal da Paraíba, Areias.

INSTITUTO BRASILEIRO DE GEOGRAFIA E ESTATISCICA - IBGE. Produção pecuária municipal, Brasil. Rio de Janeiro: IBGE, 2010. 110 p.

ISHOLA, M. M.; AGBAJI, E. B. A chemisty study of Tamarindus indica L (tsamioya) fruits grown in Nigéria. Journal of Science of Food and Agriculture, London, v. 51, n. 1, p. 141-143, 1990.

LEFEVRE, J. J. Revier de la littérature sur le tamarinier. Fruits, Paris, v. 26, n. 10, p. 687-695, 1971.

LEITE, D. F. L.; AGUIAR, E. M.; HOLANDA, J. S.; RANGEL, A. H. N.; AURELIANO, I. P. L.; MEDEIROS, V. B.; LIMA JÚNIOR, D. M. Valor nutritivo do resíduo de caju desidratado associado a diferentes concentrados. Acta Veterinaria Brasilica, Mossoró, v. 7, n. 1, p. 66-72, 2013.

NATIONAL RESEARCH COUNCIL - NRC. Nutrients requirements of small ruminants: sheep, goats, cervids and new world camelids. Washington, D. C.: National Academy Press, 2007. 384 p.

OSÓRIO, J. C.; OLIVEIRA, N. M.; JARDIM, P. O.; MONTEIRO, E. M. Produção de carne em ovinos de cinco genótipos: 2. Componentes do peso vivo. Ciência Rural, Santa Maria, v. 26, n. 3, p. 471-475, 1996.

PEREIRA, P. C.; MELO, B.; FRAZÃO, A. A.; ALVES, P. R. B. A cultura do tamarindo (Tamarindus indica $L$ ). Revista Brasileira de Fruticultura, Cruz das Almas, v. 8, n. 1, p. 45-48, 1986.

PLATAFORMA DA OVINOCAPRINOCULTURA PARA O CENTRO-OESTE - UnB. Atualidades na criação de ovinos no Brasil central. Brasília: CNPq/ COAGR/UnB, 2001. 56 p.

RAMOS, P. R.; PRATÊS, E. R.; FONTANELLI, R. S.; BARCELLOS, J. O. J.; LANGWINSKI, D.; BONELLI, I. B. Uso do bagaço de mandioca em substituição ao milho no concentrado para bovinos em crescimento. Revista Brasileira de Zootecnia, Viçosa, MG, v. 29, n. 1, p. 295-299, 2000.
RODRIGUES, D. N.; CABRAL, L. S.; LIMA, L. R.; ZERVOUDAKIS, J. T.; GALATI, R. L.; OLIVEIRA, A. S.; COSTA, D. P. B.; GERON, L. J. V. Desempenho de cordeiros confinados, alimentados com dietas à base de torta de girassol. Pesquisa Agropecuária Brasileira, Brasília, v. 48, n. 4, p. 426-432, 2013.

SECRETARIA DE ESTADO DE PLANEJAMENTO E DESENVOLVIMENTO ECONÔMICO - SEPLAN. Zoneamento sócio econômico e ecológico do estado de Mato Grosso. Cuiabá: SEPLAN, 2007. Disponível em: $<$ http://www.zsee.seplan.mt.gov.br/divulga $>$. Acesso em: 25 out. 2013.

SILVA, J. F. C.; LEÃO, M. I. Fundamentos de nutrição de ruminantes. Piracicaba: Livro Ceres, 1979. 380 p.

SNIFFEN, C. J.; O'CONNOR, J. D.; VAN SOEST, P. J.; FOX, D. G.; RUSSELL, J. B. A net carbohydrate and protein system for evaluating cattle diets: II. Carbohydrate and protein availability. Journal of Animal Science, Champaign, v. 70, n. 10, p. 3562-3577, 1992.

SOUZA JÚNIOR, A.; GIRÃO, R. N.; GIRÃO, E. S.; GIRÃO, C. S. Manejo alimentar de caprinos e ovinos. Teresina: série Aprisco, 2004. v. 5, 46 p.

UNIVERSIDADE FEDERAL DE VIÇOSA - UFV. Sistemas de análises estatísticas e genéticas - SAEG. Versão 9. 1. manual do usuário. Viçosa, MG: Imprensa Universitária, 2007. 150 p.

VAN SOEST, P. J. Nutritional ecology of the ruminant. $2^{\text {th }}$ ed. London: Constock Publishing Associates, 1994. $476 \mathrm{p}$.

VAN SOEST, P. J.; ROBERTSON, J. B.; LEWIS, B. A. Methods for dietary fiber neutral detergent fiber, and no starch polysaccharides in relation to animal nutrition. Journal of Dairy Science, Champaign, v. 74, n. 12, p. 3583-3597, 1991.

VASCONCELOS, V. R.; LEITE, E. R.; ROGÉRIO, M. C. P.; PIMENTEL, J. C. M.; NEIVA, J. N. M. Utilização de subprodutos da indústria frutífera na alimentação de caprinos e ovinos. Sobral: EMBRAPA Caprinos, 2002. 36 p. (EMBRAPA Caprinos. Documentos, 42).

VIANA, J. G. A. Panorama geral da ovinocultura no mundo e no Brasil. Revista Ovinos, Porto Alegre, v. 4, n. 12, p. 30-37, 2008.

WEISS, W. P. Energy prediction equations for ruminant feeds. In: CORNELL NUTRITION CONFERENCE FOR FEED MANUFACTURERS, 61., 1999, Ithaca. Proceedings... Ithaca: Cornell University, 1999. p. 176185. 
ZEOULA, L. M.; CALDAS NETO, S. F.; GERON, L. J. V.; MAEDA, E. M.; PRADO, I. N.; DIAN, P. H. M. Substituição do milho pela farinha de varredura de mandioca (Manihot esculenta, Crantz) em rações de ovinos: consumo, digestibilidade, balanços de nitrogênio e energia e parâmetros ruminais. Revista Brasileira de Zootecnia, Viçosa, MG, v. 32, n. 2, p. 491-502, 2003.

ZEOUlA, L. M.; PRADO, O. P. P.; GERON, L. J. V.; BELEZE, J. R. F.; AGUIAR, S. C.; MAEDA, E. M. Digestibilidade total e degradabilidade in situ de dietas volumosas com inclusão de ionóforo ou própolis para bubalinos e bovinos. Semina: Ciências Agrarias, Londrina, v. 35, n. 4, p. 2063-2076, 2014. 
